\title{
Evaluasi Model CIPP Pada Implementasi KTSP Pendidikan Agama Islam di Sekolah Menengah Atas Jombang
}

\author{
Bulhayat \\ Mahasiswa Doktoral Universiti Malaya Malaysia \\ E-mail: zhafranruby1415@gmail.com
}

\begin{abstract}
Abstrak
Penelitian ini bertujuan untuk meninjau pelaksanaan Kurikulum Pendidikan Agama Islam di Sekolah Menengah Atas Jombang. Adapun fokus kajiannya untuk mengungkap secara mendalam dari aspek pengetahuan, kelengkapan, proses belajar mengajar, dan penilaian yang dilakukan oleh Guru PAI dengan menggunakan kerangka konseptual model penilaian CIPP yang dikembangkan oleh Stufflebeam. Kajian ini menggunakan pendekatan kualitatif dengan menggunakan alat pengumpulan data seperti wawancara, observasi dan analisa dokumen. Hasil kajian ini menunjukkan bahwa kepala sekolah di Sekolah Menengah Atas Jombang telah memahami objektif dan melaksanakan Kurikulum Tingkat Satuan Pendidikan (KTSP) mata pelajaran PAI. Hasil kajian juga menunjukkan bahwa (1) Guru PAI telah memahami objektif KTSP PAI (2) Guru PAI telah membuat perencanaan pembelajaran (3) Guru PAI telah melaksanakan proses pengajaran dan pembelajaran berdasarkan kurikulum Pendidikan Agama Islam (4) Guru PAI juga telah melaksanakan dua bentuk penilaian, yaitu penilaian proses dan ujian semester. Selain itu, hasil kajian juga menunjukkan bahwa peserta didik telah memahami pengetahuan yang disampaikan oleh guru dan memproleh hasil ujian yang sesuai dengan standard penilaian yang telah ditentukan oleh sekolah dan guru.
\end{abstract}

\begin{abstract}
This study aims to review the implementation of the Islamic Education Curriculum at Jombang High School. The focus of the study is to find out the aspects of knowledge, completeness, teaching and learning processes, and assessments conducted by PAI Teachers using the CIPP assessment model conceptual framework developed by Stufflebeam. This study uses a qualitative approach using data collection tools such as interviews, observation and document analysis. The results of this study indicate that the principals in high schools has understood the objectives and implemented the Kurikulum Tingkat Satuan Pendidikan (KTSP) for PAI subjects. The results of study also found that (1) PAI teachers have understood objectively KTSP for PAI (2) PAI teachers have made learning plans (3) PAI teachers have carried out teaching and learning processes based on Islamic religious education curriculum (4) PAI teachers have also implemented two forms assessment, namely the assessment of the process and the semester exam. In addition, the results of the study also show that students have understood the knowledge conveyed by the teacher and obtained the results of tests that are in accordance with the assessment standards determined by the school and the teacher.
\end{abstract}

Keywords : CIPP, Pendidikan, Guru, Jombang.

\section{PENDAHULUAN}

Ledakan informasi di era globalisasi telah menghasilkan semua aspek kehidupan yang disesuaikan dengan visi, misi, tujuan dan strategi yang sejalan dengan kebutuhan masyarakat. Begitu pula dengan sistem pendidikan di Indonesia. Sistem pendidikan nasional selalu dikembangkan sesuai dengan kebutuhan saat ini baik lokal, nasional, dan internasional (Mulyasa, 2006). 
Pendidikan merupakan usaha sadar dan terancang untuk mewujudkan suasana belajar dan proses pembelajaran agar pelajar terlibat secara aktif dalam mengembangkan potensi dirinya dan memiliki kekuatan spritual keagamaan, pengendalian diri, kepribadian, kemahiran, akhlak mulia serta ketrampilan yang diperlukan dirinya, masyarakat, bangsa, dan negara (UU No. 20 Tahun 2003).

Sehubungan itu, pendidikan memiliki peranan penting dalam meningkatkan taraf hidup sumber daya manusia dan memastikan generasi muda dapat bersaing di dunia global. Untuk memastikan suatu pendidikan itu dapat bersaing di tingkat internasional, sangat ditentukan oleh suatu sistem dan kurikulum pendidikannya (Ikhsanul Othman \& Norila MD Saleh, 2005). Masa depan dan perkembangan suatu bangsa ditentukan oleh mutu pendidikan dan kurikulum pendidikannya. Mutu pendidikan yang bagus tidak hanya ditentukan oleh kurikulum pendidikan yang baik tetapi bergantung juga kepada peranan sekolah dan guru sebagai pelaksana kurikulum. Hal ini sesuai dengan pendapat yang dikemukakan oleh Ikhsanul Othman \& Norila MD Saleh (2005) dan Nasution (2003) bahwa untuk memastikan sistem pendidikan tidak ketinggalan dari arus perubahan globalisasi, perlu dilakukan inovasi dan memperhatikan perubahan dalam kurikulum pendidikan agar dapat membentuk peserta didik menjadi lebih kreatif dan inovatif.

Menurut Tilaar (2006) bahwa pola berpikir baru dalam pendidikan dimulai dengan model pembelajaran yang sebelumnya teacher centric dirubah menjadi siswa centric sehingga kurikulum yang dikembangkan didasarkan pada kurikulum mata pelajaran, kurikulum berpusat pada anak, dan kurikulum kecakapan hidup. Oleh karena itu, munculnya pola pikir seperti itu menciptakan dorongan untuk menampilkan sekolah-sekolah yang berprestasi dan berkualitas tinggi dan menciptakan motivasi dalam mendidik anak-anak bangsa.

Kurikulum pendidikan di Indonesia beberapa kali mengalami perubahan. Perubahan-perubahan itu berpandukan kepada perkembangan pendidikan di Indonesia itu sendiri. Perkembangan kurikulum yang dimaksud dipacu oleh pertimbangan untuk memenuhi tuntutan pada saat itu, keperluan masyarakat dan mendukung pembangunan nasional. Jika ditelusuri sejarah 
perubahan kurikulum pendidikan di Indonesia, setidaknya sudah enam kali perubahan kurikulm yaitu kurikulum 1968, kurikulum 1975, kurikulum 1984, kurikulum 2004 dan terakhir adalah kurikulum tingkat satuan pendidikan atau biasa disebut sebagai kurikulum 2006. Perubahan demi perubahan yang dilakukan sudah tentu bertujuan untuk memperbaiki dan meningkatkan kualitas pendidikan. Seperti dinyatakan oleh Mulyasa (2006), reformasi pendidikan yang dimaksud adalah bertujuan untuk melakukan perubahan sistem pendidikan yang sudah ada kepada system yang baru agar lebih sempurna dan bisa menjawab segala tantang masa depan.

\section{Landasan Yuridis KTSP}

Dalam Undang-Undang Dasar 1945 pasal 31 ayat 3 menyatakan, pemerintah mengusaha dan menyelenggarakan satu sistem pendidikan nasional yang bertujuan meningkatkan keimanan dan ketakwaan serta akhlak mulia. Hal ini bertujuan untuk mencerdaskan kehidupan bangsa yang diatur dengan undang- undang. Dalam sistem pendidikan di Indonesia, secara tegas dinyatakan bahawa fungsi pendidikan nasional adalah mengembangkan kemampuan serta meningkatkan kualitas kehidupan dan martabat masyarakat Indonesia.

Dalam Undang-undang No. 2 Tahun 1989 Bab IX, Pasal 39, Ayat 1 dicatatkan "Isi kurikulum merupakan susunan bahan kajian dan pelajaran untuk mencapai tujuan pelaksanaan satuan pendidikan yang bersangkutan dalam rangka upaya pencapaian tujuan pendidikan nasional". Kemudian, ayat 2 disebutkan bahawa isi setiap jenis, jalur dan peringkat pendidikan wajib memuat pendidikan pancasila, pendidikan agama dan pendidikan kewarganegaraan. Sedangkan dalam ayat 3 disebutkan bahwa isi kurikulum pendidikan dasar memuat sekurangkurangnya bahan kajian dan pelajaran tentang pendidikan Pancasila.

Salah satu inovasi dalam dunia pendidikan yang dilakukan oleh pemerintah saat ini ialah dengan menyempurnakan kurikulum yang lama iaitu Kurikulum Berbasis Kompetensi (KBK) dengan dikeluarkan Undang-Undang Republik Indonesia Nomor 20 Tahun 2003 tentang Sistem Pendidikan Nasional 
dan Peraturan Pemerintah Republik Indonesia Nombor 19 Tahun 2005 (PP19/2005) tentang Standard Nasional Pendidikan. Sistem yang diperkenal mengamanatkan Kurikulum Tingkat Satuan Pendidikan (KTSP) tingkat pendidikan dasar dan menengah yang disusun oleh sekolah dengan merujuk kepada Standard Isi dan Standard Kompetensi Lulusan.

Dengan lahirnya Undang-Undang Nombor 20 mengenai sistem pendidikan nasional 2003 tersebut, ia memberi impak terhadap perubahan arah dalam sistem pendidikan di Indonesia. Undang-undang tersebut menjadi pendorong kepada setiap satuan pendidikan (sekolah) untuk senantiasa meningkatkan prestasi dan kualitas dengan memanfaatkan dana pendidikan dari pemerintah Indonesia. Pasal 49 ayat 1, Undang- Undang Nomor 20 tahun 2003. Selain itu, Peraturan Pemerintah (PP) Nombor 19 Tahun 2005 tentang Standard Nasional pendidikan menetapkan delapan bagian tentang Standard Nasional Pendidikan, yiaitu Standard Isi, Standard Proses, Standard Kompetensi Lulusan, Standard Pendidik dan Tenaga Kependidikan, Standard Sarana dan Prasarana, Standard Pengelolaan, Standard Pembiayaan dan Standard Penilaian Pendidikan. kedepalapan standard nasional pendidikan ini semestinya dijadikan panduan di dalam melakukan evaluasi pelaksanaan kurikulum tingkat satuan pendidikan (Mulyasa, 2008).

Sedangkan menurut Sufean Hussin (2002) menyatakan bahwa perubahan dalam pendidikan sangat bergantung pada implementasi kurikulum yang inovatif dan kreatif di kelas. Hal ini disebabkan oleh implementasi kurikulum yang tidak inovatif dan kreatif yang menghasilkan situasi pembelajaran yang tidak menarik dan tidak efisien yang merangsang potensi siswa. Oleh karena itu, guru sebagai pelaksana kurikulum di kelas harus dapat beradaptasi dengan lingkungan belajar.

\section{Kurikulum Mata Pelajaran Pendidikan Agama Islam}

Pendidikan Agama Islam adalah bagian dari pendidikan nasional. Dalam Undang-Undang No.20 Tahun 2003 tentang sistem pendidikan nasional pasal 37 ayat 1 menjelaskan bahwa kurikulum pendidikan dasar dan menengah wajib memuatkan antara lain pendidikan agama. Dalam penjelasan berkenaan dinyatakan bahwa pendidikan agama bertujuan untuk membentuk pelajar menjadi 
manusia yang beriman dan bertaqwa kepada Tuhan Yang Maha Esa serta berakhlak mulia.

Islam sangat menyadari bahwa hanya dengan pendidikan yang lengkap dan bermutu sajalah yang dapat membimbing mnausia dalam menjalani kehidupan yang baik dan sejahtera. Sebaliknya, jika pendidikan itu lumpuh, maka kehidupan manusia menjadi kacau-balau dan tidak terkendali. Oleh karena itu, pendidikan berlandaskan ajaran Islam merupakan usaha sadar dan terencana untuk menyediakan siswa dalam meyakini, memahami, menghayati dan mengamalkan ajaran Islam melalui bimbingan guru.

Menurut Abdul Halim El-Muhammady (1991) pendidikan Islam adalah suatu proses mendidik dan melatih akal, emosi berdasarkan sumber wahyu $\mathrm{Al}-$ Qur'an serta sunnah, pengalaman salaf serta ilmuan muktabar untuk melahirkan insan yang mampu memikul tanggungjawab sebagai khalifah di alam ini. Ahmad Mohd. Salleh (1997) pula menyatakan, pendidikan Islam merupakan proses mendidik dan melatih aqliah, jasmaniah serta rohaniah manusia berdasarkan nilainilai Islamiah yang bersumberkan wahyu Al-Qur'an dan Sunnah dalam melahirkan manusia yang bertaqwa dan mengabdikan diri semata-mata kepada Allah.

\section{Evaluasi Kurikulum}

Penilaian kurikulum merupakan salah satu proses dalam pengembangan pelaksanaan kurikulum, oleh karena itu penilaian tidak saja diperlukan pada saat program sudah dilaksanakan akan tetapi penilaian juga dilaksanakan pada saat proses pelaksaan. Adapun penilaian yang dimaksud ialah penilaian formatif dan sumatif. Penilaian formatif dilaksanakan pada saat proses pelaksaan kurikulum, sedangkan penilaian sumatif yaitu untuk memastikan apakah tujuan kurikulum tersebut dapat dicapai atau tidak oleh peserta didik.

Penilaian merupakan salah satu komponen penting dalam melihat keberhasilan pelaksanaan kurikulum yiaitu untuk melihat pencapaian tujuantujuan pendidikan yang ingin diwujudkan melalui kurikulum yang diperkenalkan. Hal ini seperti dinyatakan oleh Forrest W. Parkay (2010) yiaitu "Curriculum 
evaluation involves making systematic judgments about the quality, or value, of educational programs in a school or district and developing strategies for improving those programs". Menurutnya juga "When evaluating a curriculum, remember to gather data that represent not just the written, taught, and learned curriculum, but also the hidden and experienced curriculum”. Selain itu, Ornstein \& Hunkins ( 2009) juga menyatakan hal yang senada bahwa "Evaluation is a process whereby people gather data in order to make decisions".

Menurut Arikunto (2002), evaluasi adalah bagian dari sistem manajemen perencanaan, pengorganisasian, pelaksanaan, pemantauan dan evaluasi. Dengan demikian, kurikulum diatur secara bertahap dari tahap desain, pengorganisasian kemudian implementasi dan akhirnya pemantauan dan evaluasi. Karena itu, evaluasi adalah rangkaian yang dilakukan dengan sengaja untuk melihat keberhasilan program. Evaluasi kurikulum memainkan peran penting dalam penentuan kebijakan pendidikan dan pengambilan keputusan dalam kurikulum itu sendiri. Hasil evaluasi kurikulum dapat digunakan oleh para pengambil kebijakan pendidikan dan para pelkasana kurikulum dalam memilih dan menetapkan dasar untuk pengembangan sistem pendidikan sejalan dengan pengembangan model kurikulum yang digunakan.

\subsection{Tujuan Penelitian}

Penelitian ini bertujuan untuk memperoleh informasi dari pelaksanaan Kurikulum Pendidikan Agama Islam dalam konsep KTSP. Informasi diperoleh dari dimensi konteks, input, proses dan produk. Informasi ini diperlukan untuk meningkatkan, menyusun dan merencanakan inovasi kurikulum. Evaluasi terhadap status implementasi kurikulum juga memungkinkan keputusan divisi pendidikan guru untuk meningkatkan efektivitas pelaksanaannya di masa depan.

Hasil penelitian ini dapat digunakan oleh Departemen Pendidikan Nasional, khususnya pusat pengembangan kurikulum dan institusi terkait. Agar keputusan yang akan dibuat untuk meningkatkan pelaksanaannya berdasarkan pada kerangka penelitian ini. Penelitian ini juga dapat digunakan sebagai referensi untuk membuat refleksi guru sendiri pada efektivitas strategi implementasi 
kurikulum berdasarkan pandangan yang diberikan oleh kepala sekolah. Ini akan memungkinkan guru untuk merevisi strategi penerapan kurikulum pendidikan agama Islam sesuai dengan KTSP agar lebih efektif dalam mencapai tujuan yang ditetapkan oleh pembuat kurikulum.

\section{Metode Penelitian}

Penelitian ini menggunakan pendekatan kualitatif yiaitu prosedur penyelidikan yang menghasilkan data gambaran yang boleh diamati (Moleong $\mathrm{J}$, 2007). Pendekatan kualitatif yang akan digunakan dalam kajian ini adalah studi kasus, iaitu suatu penyelidikan yang dilakukan terhadap suatu kesatuan sistem, apakah berbentuk program maupun kejadian yang terikat oleh tempat, waktu (Nana, 2005). Menurut Patton (2002) pendekatan studi kasus dalam kajian kualitatif adalah salah satu cara untuk mendapatkan informasi secara komprehensif dan sistematis serta mendalam kepada satu unit kecil. Seperti individu, kelompok, budaya ataupun organisasi. Hal ini sebagaimana dinyatakan oleh Creswell 1998) bahwa suatu penelitian dapat dikatakan sebagai studi kasus manakala proses penyelidikannya dilakukan secara mendalam dan menyeluruh terhadap kasus yang dikaji. Hal yang sama juga dinyatakan oleh Noraini Idris ( 2010), bahwa penggunaan kaedah studi kasus dalam penelitian kualitatif sangat membantu peneliti dalam memahami sesuatu masalah atau fenomena secara terperinci dan mendalam.

Menurut Bogdan dan Biklen (1982) kajian kes merupakan pengujian secara terperinci terhadap satu latarbelakang atau satu orang subjek atau tempat atau peristiwa tertentu. Kajian kes melibatkan secara intensif keterangan yang holistik dan analitik daripada satu contoh atau unit sosial (Merriam, 2001). Menurut Yin (1995), penggunaan rekabentuk penyelidikan kajian kes menggunakan data kualitatif amat sesuai apabila sesuatu kajian melibatkan pemerhatian terhadap seseorang individu atau unit, suatu kumpulan manusia, aktiviti bilik darjah, sekolah dan masyarakat. Oleh itu, suatu kajian kes harus memfokuskan kepada subjek yang mempunyai sesuatu kriteria atau ciri-ciri yang akan dikaji. 
Penelitian dengan metode studi kasus disini sebagai suatu cara untuk memahami dan menafsirkan fakta yang terjadi di lapangan, serta mengetahui cara yg lebih mendalam bagaimana metode pembelajaran PAI yang dilakukan oleh guru dan bagaimana respon siswa terhadap metode tersebut. Adapun teknik pengumpulan data dilakukan dengan observasi, wawancara mendalam (depth interview), dan dokumentasi. Adapun analisis data dilakukan dengan menggunakan intraktif seperti yang dikembangkan oleh Mile \& Huberman, yaitu pengumpulan data, reduksi data, display data, dan mengambil kesimpulan.

\subsection{Model Penelitian}

Bagian ini membahas konsep konsep evaluasi kurikulum, implementasi kurikulum berdasarkan kerangka teori studi dan pemilihan rasional model evaluasi CIPP sebagai kerangka teori implementasi kurikulum tingkat satuan pendidikan. Model CIPP (konteks, masukan, proses, produk) disajikan dalam buku berjudul 'Evaluation Models' (1983) dan dikembangkan oleh Stufflebeam pada tahun 1960an. Ide ini telah digunakan sebagai salah satu alternatif untuk melihat peringkat yang sangat populer hari ini.

Pendekatan CIPP didasarkan pada bahwa tujuan evaluasi bukan untuk memberikan bukti tetapi untuk meningkatkan program yang telah direncanakan (Stufflebeam, 1983). Seperti penelitian yang dilakukan oleh Mohd Nasrudin Basar (2006) untuk menilai status pelaksanaan kurikulum pendidikan Malaysia dengan menggunakan model (CIPP, 1971) telah digunakan sebagai model kerangka penelitian untuk menjawab pertanyaan-pertanyaan penelitiannya. Dia juga menggunakan ke empat dimensi CIPP yaitu dimendi konteks, masukan, proses dan produk. Definisi penilaian dalam penelitian ini mengacu pada model CIPP (Stufflebeam, 1971). Penilaian konteks ditujukan untuk menginformasikan keputusan perencanaan, Evaluasi Input adalah untuk melayani keputusan struktural, sedangkan Evaluasi Proses adalah untuk memandu keputusan implementasi, dan Penilaian Produk untuk melayani pengambilan keputusan ulang. Untuk memfasilitasi klarifikasi penggunaan kerangka teoritis dalam penelitian ini, peneliti membagi penilaian pelaksanaan kurikulum tingkat unit 
menjadi empat fase berdasarkan dimensi penilaian konteks, input, proses dan produk. Untuk lebih jelasnya ikuti bagan model penelitian berdasarkan model CIPP.

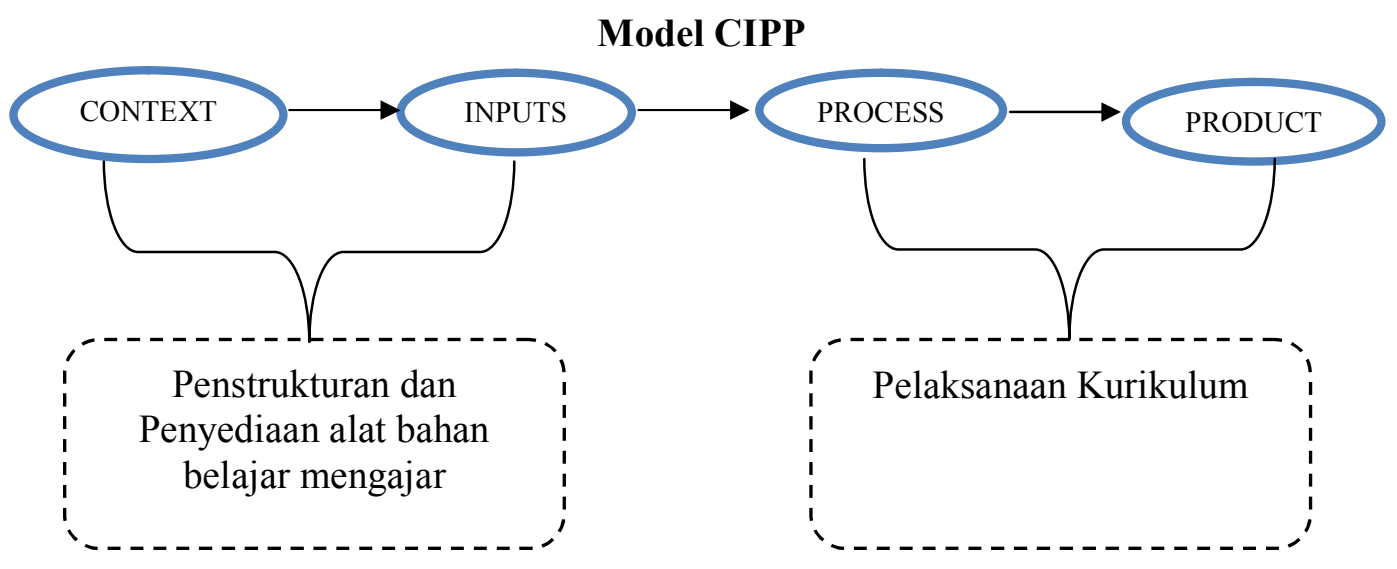

\section{Dimensi Konteks}

Penilaian konteks dilakukan untuk menilai situasi dalam pelaksanaan program, kebutuhan yang perlu dipenuhi oleh kurikulum dan untuk mengidentifikasi kekuatan dan kelemahan dari institusi, program, dan target populasi (Stufflebeam, 1983). Penilaian konteks adalah penilaian tujuan dasar untuk menyelesaikan desain studi evaluasi program. Oleh karena itu, tujuan dari penilaian konteks adalah untuk mengevaluasi tujuan dan sasaran dari kurikulum tingkat satuan pendidikan yang dilaksanakan. Adapun tujuan dari kurikulum tingkat satuan pendidikan adalah sebagai berikut:

1. Meningkatkan kualitas pendidikan melalui kemandirian dan inisiatif sekolah dalam mengembangkan kurikulum, mengelola dan memberdayakan sumber daya yang tersedia.

2. Meningkatkan kesadaran anggota sekolah dan masyarakat dalam pengembangan kurikulum melalui pengambilan keputusan bersama.

3. Meningkatkan persaingan sehat antar sekolah berdasarkan kualitas pendidikan yang ingin dicapai.

\section{Dimensi Input}


Evaluasi input adalah evaluasi yang bertujuan menyediakan informasi untuk menentukan bagaimana penggunaan sumberdaya untuk mencapai tujuan program. Penilain input meliputi guru, peserta didik, kurikulum dan bahan ajar. Evaluasi input bermanfaat bagi membimbing bagi pemilihan strategi sehingga informasi dan data yang didapatkan dapat digunakan untuk menentukan sumber dan strategi dalam keterbatasan (Stufflebeam, 1983).

Oleh karena itu, evaluasi pelaksanaan dimensi input dalam kajian ini adalah untuk mengetahui desain pelaksanaan kurikulum dengan tujuan mencari strategi pelaksanaan. Terdapat tiga strategi pelaksanaan kurikulum yaitu strategi pengajaran yang berpusatkan kepada guru, strategi berpusatkan kepada murid dan strategi pengajaran berpusatkan kepada nilai (Nasaruddin, 2006).

\section{Dimensi Proses}

Penilaian proses yaitu pengumpulan data untuk memperoleh informasi tentang pelaksanaan kurikulum tingkat satuan pendidikan sebagaimana yang diamanatkan oleh perancang kurikulum tingkat satuan pendidikan. Menurut model CIPP (Stufflebeam, 1983), salah satu tujuan penilaian proses adalah untuk melihat apakah pelaksanaan program sudah sesuai dengan strategi yang telah dilaksanakan. Evaluasi proses termasuk mengidentifikasi permasalahn prosedur pada pelaksanaan. Stufflebeam juga mengatakan bahwa evaluasi proses merupakan pengecekan yang berkelanjutan atas inplementasi dari suatu perencanaan.

Penilaian proses dalam kajian ini juga memfokuskan kepada bagaimana guru sebagai pelaksanan kurikulum melaksanakan proses pengajaran dan pembelajaran di dalam kelas, yang meliputi penggunaan strategi pengajaran dan alat bantu mengajar.. Menurut Sowell (2000), pertanyaan yang perlu dijawab dalam penilaian proses adalah bagaimana guru dapat melaksanakan peranan dan tugasnya seperti yang telah ditetapkan dalam kurikulum tingkat satuan pendidikan.

\section{Dimensi Produk}


Menurut model CIPP (Stufflebeam, 1983), evaluasi produk adalah evaluasi untuk mengukur, menginterpretasikan dan mengevaluasi pencapaian program. Penilaian ini juga dapat menunjukkan hubungan antara pelaksana kurikulum dengan keberhasilan pembelajaran yang diperoleh. Penilaian produk dalam kajian ini berdasarkan hasil pembelajaran yang dicapai setelah mengikuti pembelajaran kurikulum tingkat satuan pendidikan. Fokus penilaian produk dalam kajian ini bertujuan mengetahui pencapaian tujuan kurikulum (Nasaruddin, 2006).

\section{Hasil dan Pembahasan Penelitian}

Pendidikan Agama Islam merupakan salah satu mata pelajaran yang wajib dalam semua jenjang sistem pendidikan nasional. Kajian ini berdasarkan kepada Model CIPP yang diterapkan oleh Stufflebeam. Dengan memfokuskan kepada empat dimensi yaitu dimensi Konteks, Input, Proses dan Produk.

1. Dimensi konteks

a. Tujuan pencapaian dalam melaksanakan Kurikulum Tingkat Satuan Pendidikan dalam sekolah menengah atas negeri?

B) Dimensi Input

a. Kesediaan guru di dalam melaksanakan KTSP dalam sekolah menengah atas negeri.

b. Sumber belajar dalam pelaksanaan KTSP di Sekolah menengah atas negeri.

C) Dimensi Proses

a. Proses pengajaran dan pembelajaran di sekolah.

b. Permasalahan yang dijumpai dalam pelaksanaan KTSP

D) Dimensi Produk

a. Hasil pengajaran dan pembelajaran dapat dicapai dalam pelaksanaan KTSP 


\section{Komponen Konteks ( Context)}

Komponen dalam konteks difokuskan pada peringkat lembaga pendidikan yaitu pada kemampuan guru dalam melaksanakan PAI. Pada bagian ini dapat memberikan informasi penting terhadap pemerimtah dalam membuat kebijakan.

\section{a) Tujuan Pelaksanaan Kurikulum Tingkat Satuan Pendidikan PAI}

Melalui KTSP, pihak sekolah diberikan kebebasan untuk mengembangkan kurikulum dan metode pembelajaran yang sesuai dengan tujuan sekolah. Oleh kerana itu untuk mewujukan tujuan tersebut, sekolah ditumtut untuk mengembangkan standart kemahiran ke dalam indicator persaingan. Selain itu sekolah juga dituntut untuk memanfaatkan berbagai potensi dan alam sekitar.

Berdasarkan kesimpulan dari tujuan pelaksanaan KTSP di ketiga sekolah ini, para guru PAI telah mempelajari filosofi dan tujuan KTSP yang merupakan proses pembelajaran yang berpusat pada peserta didik. Siswa diberi tanggung jawab dan efektivitas parsial dalam menentukan arah pembelajaran sementara guru berperan sebagai fasilitator untuk memotivasi, membimbing dan memantau proses pembelajaran. Hal ini sejalan dengan Standar Nasional Pendidikan yang merancang KTSP, yang implementasinya di setiap sekolah akan membentuk warna yang berbeda, sesuai dengan kebutuhan daerah, karakter sekolah dan kemampuan siswa.

\section{Hasil Penelitian Dimensi Input}

Tahap kedua dari model CIPP adalah evaluasi masukan. Adapun tujuan utama evaluasi ini adalah untuk mengaitkan tujuan, konteks, input, proses dengan hasil program. Evaluasi ini juga untuk menentukan kesesuaian lingkungan dalam membantu pencapaian tujuan objektif program.

\section{a) Kesediaan guru PAI dalam melaksanakan KTSP PAI}

Sebelum melaksanakan kegiatan pembelajaran, setiap guru diharapkan mampu menyiapkan diri dengan membuat perancangan program sekaligus sebagai kelengkapan pengurusan pembelajaran. Menyentuh berkenaan perancangan pembelajaran, guru PAI terlebih dahulu perlu membuat silibus dan Rencana Pengajaran dan Pembelajaran (RPP) berdasarkan SK-KD hal ini sejalan dengan 
ketentuan yang telah ditetapkan oleh Badan Standard Nasional Pendidikan. adapun komponen penunjang RPP yang merangkumi: 1) Bagian pembukaan, 2) Standard Kompetensi, 3) Kompetensi Dasar, 4) Indikator, 5) Tujuan Pembelajaran, 6) Bahan Pembelajaran, 7) Metode Pembelajaran, 8) Langkahlangkah Pembelajaran, 9) Alat dan sumber belajar, dan 10) Penilaian.

\section{b) Kesediaan Bahan Bantu Mengajar}

Era teknologi saat ini telah mengubah proses pengajaran dan pembelajaran di kelas yang tidak saja tertumpu pada buku teks, kapur tulis atau papan tulis. Selain itu persiapan dan penggunaan teknologi sebagai bahan bantu mengajar untuk menumbuhkan minat belajar siswa di kelas sangat diperlukan.

Dalam penilaiaan fasilitas belajar, peneliti melakukan observasi terhadap proses belajar mengajar dalam kelas. Adapun hasil observasi yang diperoleh adalah sebagai berikut: Mendapati menemukan bahwa kelas-kelas dalam sumber belajar kelas dilengkapi dengan peralatan elektronik (multimedia) seperti seperangkat komputer, televisi dan pemain VCD, serta LCD. Peralatan ini sesuai dengan standar peralatan dan infrastruktur

Dari pengamatan ini, jelas bahwa: 1) kondisi kelas mendukung proses pembelajaran, ruangan cukup luas dan sistem yang bersih dan berventilasi baik, 2) alat atau sumber belajar yang ada sangat membantu proses pembelajaran. Selain itu, guru pendidikan agama Islam juga tampil dekat dengan siswa mereka sehingga memudahkan proses pembelajaran di kelas.

\section{Komponen Proses (Process)}

Evaluasi proses dalam model CIPP diarahkan pada seberapa jauh kegiatan yang dilaksanakan sudah terlaksana sesuai dengan rencana, seperti permasalahan guru PAI dalam melaksanakan KTSP. Situasi belajar yang efektif dapat dicapai jika guru mampu mengendalikan siswa dan peralatan belajar dan membangun hubungan persahabatan dengan siswa serta mengendalikannya dalam suasana yang menyenangkan untuk mencapai tujuan pembelajaran. Situasi belajar yang efektif mempengaruhi kualitas pelaksanaan pembelajaran. 
Untuk mengetahui pelaksanaan pembelajaran, peneliti melakukan observasi terhadap proses pengajaran dan pembelajaran. Adapun temuan observasi mengungkapkan bahwa proses belajar mengajar didiversifikasi oleh guru PAI sebagai berikut: 1) guru menggunakan modul, 2) menggunakan alat bantu pengajaran, komputer, LCD, TV, 3) Menjelaskan materi, 4) siswa untuk bertanya atau memberikan pendapat tentang apa yang dikatakan guru, 5) guru mendistribusikan kertas pertanyaan kepada setiap siswa.

\section{a) Masalah yang ditemukan dalam pelaksanaan pengajaran dan pembelajaran PAI di kelas}

Pelaksanaan pengajaran dan pembelajaran KTSP PAI di SMU menghadapi kendala karena secara resmi ditentukan bahwa alokasi waktu adalah dua kali seminggu dari 90 menit. Namun, banyak mata pelajaran yang terdiri dari lima standar kompetensi dan 17 kompetensi dasar. Lima mata pelajaran tersebut adalah Al-Quran, Aqidah, Akhlak, Fiqh, Tanggal dan Budaya Islam. Semua mata pelajaran ini membutuhkan siswa untuk memahami dan menerapkannya dalam kehidupan sehari-hari.Dengan waktu yang terbatas dialokasikan, proses belajar mengajar tidak dapat berjalan dengan lancar. Bahkan, beberapa mata pelajaran yang diajarkan tidak mencapai target yang ditetapkan dalam RPP. Temuan ini juga menunjukkan bahwa jam terbatas waktu belajar dalam pengajaran dan pembelajaran PAI yang hanya 90 menit seminggu dapat mempengaruhi kualitas hasil pengajaran, terutama budidaya nilai-nilai agama dalam kehidupan sosial siswa atau pada hasil penilaian afektif dan psikomotor.

\section{Hasil Penelitian Dimensi Produk}

Penilaian dimensi produk dalam pelaksanaan KTSP PAI difokuskan pada metode penilaian yang digunakan oleh guru PAI dan hasil belajar yang dicapai oleh siswa. Oleh karena itu, bagian ini membahas temuan dari dua kategori responden yaitu guru PAI dan dua siswa masing-masing kelas satu dan dua.

\section{a) Penilaian Pengajaran dan Pembelajaran dalam KTSP PAI}

Kegiatan evaluasi dalam penelitian ini bertujuan untuk mengetahui sejauh mana keberhasilan siswa dalam memahami nilai-nilai subyek PAI yang 
disampaikan oleh guru. Pada tahap ini, seorang guru dituntut memiliki kemampuan untuk menentukan pendekatan dan sarana penilaian, persiapan alat penilaian, pemrosesan dan penggunaan hasil penilaian.

Hasil observasi menunjukkan bahwa kegiatan evaluasi yang dilakukan oleh guru mata pelajaran PAI termasuk penilaian dasar dan proses kontrol (psikomotorik, afektif dan kognitif). Evaluasi proses dilakukan dengan melihat aktivitas siswa dalam kegiatan pembelajaran. Ini termasuk diskusi atau bahkan ketika guru menangani sesi tanya jawab. Dengan demikian, penilaian dilakukan oleh guru melalui metode observasi pada kemampuan siswa untuk menjawab pertanyaan yang diberikan baik dalam bentuk lisan atau tulisan. Selain itu analisis dokumen dilakukan pada hasil belajar siswa melalui nilai ulangan harian, ditemukan dari 31 siswa kelas sua, semua mencapai hasil ujian 78. Nilai ini sesuai dengan standar yang telah ditetapkan oleh guru.

\section{Hasil Penelitian Katagori Siswa}

Selain itu, hasil wawancara menunjukkan pemahaman siswa sangat memahami materi yang disampaikan oleh guru, karena metode yang digunakan oleh guru sangat baik, jelas dan mudah dimengerti dan tidak membosankan karena metode yang digunakan seperti penggunaan film tidak menyebabkan mereka merasa ngantuk dan menggunakan contoh-contoh yang berkaitan dengan kehidupan sehari-hari.

Hasil wawancara diatas didukung oleh temuan analisis dokumen yang dilakukan oleh peneliti. Diantaranya dokumen hasil ujian di setiap semester menunjukkan bahwa setiap siswa telah mencapai hasil ujian sesuai dengan standar penilaian. Meskipun masih ada bebrapa siswa yang harus mengikuti program kelas konseling karena belum mencapai hasil ujian yang memuaskan.

\section{Penutup}

Secara keseluruhan, penelitian ini telah memenuhi tujuan penelitian dan menjawab pertanyaan penelitian. Adapun kesimpulan secara umum evaluasi model CIPP pada implementasi KTSP Pendidikan Agama Islam SMA Wahid 
Hasyim Tebuireng Jombang telah berjalan dengan baik (sistematik, terencana, teratur, dan berkesinambungan), pada pada dimensi context, input, Proses, maupun product. Kesimpulan dari penelitian ini sebagai berikut:

1. Dalam evaluasi context pada implementasi KTSP sudah berjalan dengan baik, di tinjau dari guru, siswa, fasilitas, peraturan, komite dan masyarakat dalam mendukung terwujudnya pelaksanaan KTSP, khususnya mata pelajaran pendidikan agama islam.

2. Dalam evaluasi input pada Implementasi KTSP, kurikulum KTSP sudah berjalan sesuai aturan yang ada di sekolah. ditinjau dari aspek pelaksanaan, rancangan, dan strategi pembelajaran berdasarkan KTSP.

3. Dalam evaluasi proses pada Implementasi KTSP kendala dalam Pelaksanaan KTSP yaitu masih minimnya sarana dan prasarana dan keterbatasan jam belajar. Pengembangan dalam proses pembelajaran sudah berjalan dengan baik dengan menciptakan model-model pembelajaran.

4. Dalam evaluasi Product pada Implementasi KTSP sudah berjalan dengan baik, ditinjau dari hasil belajar dan peningkatan pada prestasi akademik. Oleh karenanya kalau ditinjau dari evaluasi kurikulum KTSP dapat di lanjutkan.

\section{Daftar Rujukan}

Abd. Rahman A. Politik Pendidikan Nasional, Pergeseran Kebijakan Pendidikan Agama Islam dari Proklamasi ke Reformasi. Yoyakarta: Kurnia Kalam, 2005.

Abdul Halim El-Muhammady, Pendidikan Islam : Falsafah, Disiplin dan Peranan Pendidik. Petaling Jaya: Dewan Pustaka Islam, 1991.

Ahmad Mohd. Salleh .(1997). Pendidikan Islam: Falsafah, Pedagogi dan Metodologi. Shah Alam: Fajar Bakti.

Aini Hasan. Penggunaan pelbagai teknik mendapatkan data kualitatif pengetahuan guru. Dalam Marohaini Yusoff (ed.), Penyelidikan Kualitatif:Pengalaman kerja lapangan. Kuala Lumpur: Penerbit Universiti Malaya, 2001.

Arikunto, Suharsimi, Dasar-Dasar Evaluasi Pendidikan, Jakarta: Bumi Aksara, 2002.

Badan Standar Nasional Pendidikan, Panduan penyusunan kurikulum tingkat satuan pendidikan. Jakarta, 2006. 
Bogdan, C. R., \& Biklen, S. K. Qualitative research for education: An introduction to theory and method. Needham Heights, MA: Allyn\&Bacon, 1998.

Bogdan, C. R., \& Biklen, S. K. Qualitative research for education: An introduction to theory and methods. Boston: Allyn, 1992.

Creswell, J. W. (2005). Educational Research : Planning, conducting, and evaluating quantitative and qualitative research $-2^{\text {nd }}$ ed. Columbus, Ohio/ U.S.A. Pearson Prentice Hall/ Pearson education, Inc.

Departemen Agama Republik Indonesia, Pendidikan Agama Islam di Sekolah Umum dan Sekolah Luar Biasa. Jakarta, 2003.

Departemen Agama Republik Indonesia, Model kurikulum tingkat satuan pendidikan. Madrasah Aliah. Jakarta, 2007.

Departemen Pendidikan Nasional, Panduan Kurikulum Tingkat Satuan Pendidikan. Jakarta, 2006.

Depdiknas, Peraturan Pemerintah, Nomor 19, Tahun 2005, tentang Standar Nasional Pendidikan. Jakarta, 2005.

H.A.R. Tilaar, Standarisasi Pendidikan Nasional: Suatu Tinjauan Praktek, Jakarta: Rineka Cipta, 2005.

Ikhsan Othman \& Norila MD Saleh, Kurikulum dan Pengajaran Sekolah Rendah “Aspek-aspek yang berkaitan”. Kuala Lumpur, Quantum Books, 2005.

Miles, M.B., \& Huberman, A.M. Qualitative Data Analysis ( $2^{\text {nd }}$ ed.). Thousand Oaks, CA: Sage Publications, 1994.

MPR RI, Undang-undang Dasar Negara Republik Indonesia. Jakarta: Sekertaris MPR RI, 2005.

Mulyasa, Kurikulum Tingkat Satuan Pendidikan; sebuah panduan praktis. Bandung. PT. Rosdakarya, 2006.

Mulyasa, Kurikulum Berbasis Kompetensi Konsep, Karakteristik, Implementasi, dan Inovasi. Bandung: PT. Remaja Rosdakarya, 2003.

Mulyasa, Implementasi Kurikulum Tingkat Satuan Pendidikan' Kemandirian Guru dan Kepala Sekolah, PT. Bumi Aksara, Jakarta, 2008.

Nana Syaodih Sukmadinata, Pengembangan Kurikulum: Teori dan Praktik, Bandung: Remaja Rosdakarya, 2000.

Nasution. S. Pengembangan Kurikulum. Bandung: Citra Aditya Bhakti, 1991.

Noraini Idris, Penyelidikan dalam Pendidikan. Kuala Lumpur: McGraw-Hill Sdn. Bhd, 2010.

Noraini Mohd Salleh, Pelaksanaan Inovasi : Implikasinya ke atas perancang kurikulum dan penyelidikan. Dalam Saedah Siraj (Ed.), Perkembangan kurikulum teori dan amalan, Kuala Lumpur: Alam Pintar Enterprise, 2000. 
Ornstein, C Allan., \& Hunkins P.Francis, Curriculum; foundations, principles, and issues. U.S.America : Pearson Edition, Inc, 2009.

Othman Lebar, Penyelidikan Kualitatif: Pengenalan kepada teori dan metod. Tanjong Malim: Penerbit Universiti PendidikanSultan Idris, 2007.

Patton, Michael Quinn, Qualitative Research \& Evaluation Methods 3ed: Thousand Oaks, California. Sage Publications, 2002.

Stufflebeam. D.L, The CIPP Model for Program Evaluation. Dalam Madaus. George F. Evaluation Models : Viewpoints on Educational and Human Services Evaluation, 1983.

Sufean Hussin, Inovasi Dasar Pendidikan: Perspektif Sistem Dan Organisasi, Kuala Lumpur Universiti Malaya, 2002.

Sufean Hussin, Pendidikan di Malaysia : Sejarah, sistem dan falsafah, Kuala Lumpur, Dewan Bahasa dan Pustaka, 2004.

Yin, R. K. Case Study Research: Design and Methods (2 ${ }^{\text {nd }}$ ed. Vol.5) Thousand Oaks: Sage Publications, 1995. 